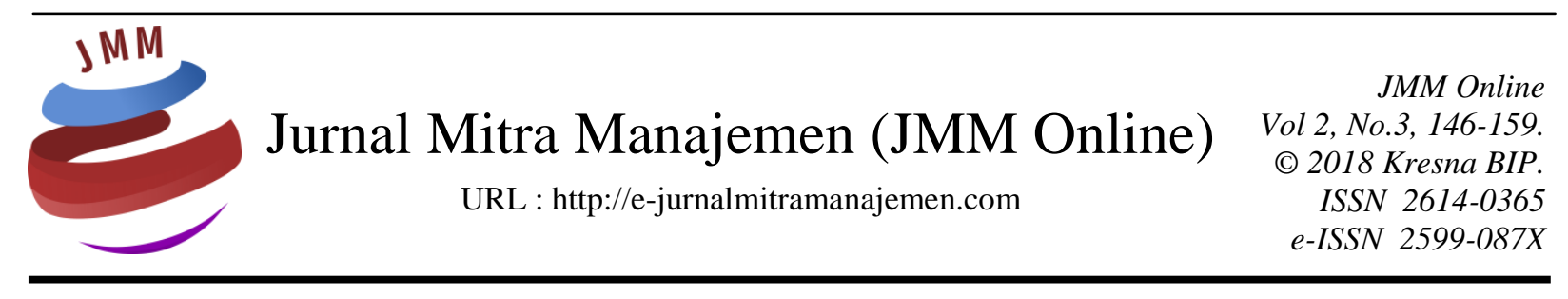

\title{
RELATIONSHIP MARKETING, POWER DAN LOYALITAS PADA HUBUNGAN BISNIS ANTARA PEMASOK DENGAN PERITEL
}

\author{
I Dewa Nyoman Arta Jiwa \\ Universitas Panji Sakti
}

INFORMASI ARTIKEL

Dikirim : 12 Mei 2018

Revisi pertama : 16 Mei 2018

Diterima : 17 Mei 2018

Tersedia online : 31 Mei 2018

Kata Kunci : Relationship marketing, power, business to business, loyalitas

Email : idnarta0874@gmail.com

\begin{abstract}
ABSTRAK
Terdapat hubungan antara relationship marketing, power dan loyalitas dalam industri di Indonesia khususnya pada peritel dan pemasok. Hubungan business to business (B2B) tersebut terkait dengan penggunaan pengaruh untuk mengikuti kemauan salah satu pihak dalam hubungan bisnis. Salah satu masalah penting dalam penggunaan power perusahaan terhadap mitra bisnisnya adalah adanya fenomena kesenjangan kekuasaan (Jain et al, 2014; Martadisastra, 2017; Setyawan, 2014). Pemahaman, identifikasi dan kemampuan menggunakan strategi pengaruh akan memperkuat posisi tawar-menawar pelaku bisnis terhadap mitra bisnis mereka. Hal ini bisa menghindarkan dari resiko tereksploitasi oleh kekuasaan yang dominan. Pemasok dari skala usahanya sebagian besar merupakan perusahaan kecil dan UMKM. Posisi pemerintah sebagai penyusun dan penegak regulasi bisnis bisa memfaatkan hasil pemikiran dan temuan penelitian yang telah dilakukan sebagai dasar untuk menyusun dan menegakkan sebuah kebijakan kemitraan bisnis antara perusahaan besar dan UMKM.
\end{abstract}




\section{PENDAHULUAN \\ Latar Belakang}

Penerapan kekuasaan atau kekuatan (power) merupakan salah satu isu penting dan krusial dalam relationship marketing. Kekuasaan disini yang dapat berupa pengaruh paksaan maupun tidak antara hubungan bisnis pemasok dan perusahaan (Jain et al, 2014). Kekuasaan dalam hubungan business to business (B2B) antara dua perusahaan adalah terkait dengan penggunaan pengaruh untuk mengikuti kemauan salah satu pihak dalam sebuah hubungan bisnis. Salah satu masalah penting dalam penggunaan kekuasaan sebuah perusahaan terhadap mitra bisnisnya adalah adanya fenomena kesenjangan kekuasaan (Setyawan, 2014). Pola hubungan bisnis antara perusahaan pengolahan makanan dengan pemasoknya di Finlandia menemukan bahwa dalam sebuah hubungan bisnis yang asimetris, kepercayaan kepada mitra bisnis terkait dengan kontrol, ukuran perusahaan dan reputasi mitra bisnis (Suvanto, 2012). Studi yang dilakukan oleh Zhuang \& Zhou dalam Sergio et al. (2014) menguraikan 6 kekuasaan mendasar yang berpengaruh dalam B2B Relationship Marketing yaitu ; reward, coercive, expert, legitimate, referent dan information. Menurut Palmatier (2008) Relationship Marketing adalah proses mengidentifikasi, mengembangkan, memelihara dan hubungan pertukaran relasional yang bertujuan untuk meningkatkan kinerja). Penelitian yang dilakukan Palmatier (2008) berkaitan dengan relasi bisnis menunjukkan bahwa membangun hubungan yang kuat dalam bisnis B2B lebih efektif dalam meningkatkan kinerja perusahaan dibandingkan dengan hubungan bisnis dengan pasar konsumen langsung. Transakasi bisnis dalam hubungan B2B dipengaruhi oleh kepercayaan dari masing-masing pihak sehingga hubungan bisnis dapat berjalan baik, mengurangi konflik dan bersifat jangka panjang. Kekuasaan dalam Relationship Marketing B2B antara pemasok dan peritel akan berdampak pada kinerja bisnis. Dimana kepuasan dalam hubungan bisnis dipengaruhi oleh kepercayaan dan komitmen (Jain et al, 2014). Namun demikian, penelitian Wu et al., (2012) tidak menggunakan konstruk kekuasaan sebagai variabel anteseden dan tidak menggunakan analisis dyadic. Variabel komitmen, kepercayaan, komunikasi, kerjasama dan konflik, kekuasaan legitimasi serta kepuasan distributor dalam industri agribisnis di Brasil diteliti oleh Sergio et al. (2014). Hasil studi kualitatifnya mengkonfirmasi bahwa terdapat hubungan strategis dalam jangka panjang yang stabil, sehingga dapat meningkatkan kepuasan yang berimbas pada peningkatan volume bisnis dan pangsa pasar.

Penelitian yang dilakukan oleh Akman \& Yorur (2012) menunjukkan bahwa terdapat 4 variabel yaitu ; kepercayaan, komitmen, komunikasi dan kerjasama pada perusahaan kecil dan menengah di negara berkembang berpengaruh pada kepuasan pemasok dan pada akhinya dapat meningkatkan loyalitas pemasok. Andersson \& Kalstroom (2014) melakukan penelitian pendekatan kualitatif mengenai faktor-faktor yang mempengaruhi kepusana dan loyalitas dalam hubungan B2B. Hasil penelitian menunjukkan terdapat 9 faktor yang berpengaruh yaitu ; kepercayaan, komitmen, komunikasi, kompetensi, penanganan konflik, empati, nilai-nilai, ikatan, dan timbak balik. Penelitian dengan pendekatan kualitatif juga dilakukan pada B2B Relationship Marketing dan cross culture dengan Hofstede's model yaitu variabel power distance (kepercayaan dan hubungan personal) di perusahaan Saudi Telecom Company (Baghdadi, 2013). 
Menurut Ehmke et al. (2009) dalam Martadisastra (2017), dalam persaingan, pemasok dapat memiliki power baik dalam posisi tawar lemah atau kuat, yang mempengaruhi syarat dan kondisi transaksi yang dilakukan. Transaksi pemasok dan pembeli menciptakan nilai bagi kedua pihak. Namun apabila pembeli memiliki kekuatan posisi tawar lebih besar, kemampuan pemasok untuk meraih nilai proporsi tinggi menurun dan laba lebih rendah. Kekuatan posisi tawar pembeli mempengaruhi besar laba yang diperoleh pemasok. Kekuatan posisi tawar pembeli adalah salah satu dari lima kekuatan yang menentukan intensitas persaingan dalam industri. Pembeli dapat mengurangi kekuatan posisi tawar pemasok dengan meningkatkan loyalitas pada pembeli melalui kemitraan atau program loyalitas.

Hubungan bisnis antara pemasok dan peritel juga terjadi pada industri garam rakyat di Indonesia yang mempunyai daerah pesisir pantai yang luas dan panjang. Potensi produksi garam yang besar, membuat banyak masyarakat di pesisir pantai menjadikannya sebagai lahan pencaharian dengan membentuk kelompok UMKM garam rakyat.

\section{Rumusan Masalah}

Berdasarkan latar belakang diatas, maka rumusan masalah dalam penelitian ini antara lain :

1. Bagaimana hubungan antara pemasok dan peritel pada industri garam rakyat di Kabupaten Buleleng.

2. Bagaimana hubungan variabel relationship marketing, power dan loyalitas pemasok dengan peritel pada industri garam rakyat di Kabupaten Buleleng.

\section{Tujuan Penelitian}

Berdasarkan rumusan masalah yang diambil, maka penelitian bertujuan untuk :

1. Melakukan identifikasi hubungan pemasok dan peritel pada industri garam rakyat di Kabupaten Buleleng.

2. Menjelaskan hubungan variabel relationship marketing, power dan loyalitas pemasok dengan peritel pada industri garam rakyat di Kabupaten Buleleng.

\section{KAJIAN PUSTAKA \\ Ilmu Pemasaran}

Setyawan (2014) menyebutkan bahwa ada tiga dikotomi dalam ilmu pemasaran, yaitu pemasaran makro dan mikro, positif dan normatif dan organisasi profit dan nonprofit. Pemasaran makro membahas tentang sistem pemasaran, dampak dari sistem pemasaran terhadap masyarakat dan dampak masyarakat terhadap sistem pemasaran. Pemasaran mikro berfokus pada aktivitas pemasaran pada level unit individual dan pemasaran internal dalam perusahaan. Pemasaran positif mencoba mendeskripsikan, menjelaskan, memprediksi dan memahami aktivitas pemasaran dan fenomena yang aktual yang ada. Pemasaran normatif mendeskripsikan apa yang harus dilakukan organisasi atau individu marketing serta apa jenis sistem pemasaran seperti apa yang harus dimiliki oleh masyarakat. Penelitian ini termasuk dalam kategori penelitian pemasaran makro, positif dan dengan latar organisasi profit Bisnis ritel di Indonesia dikuasai oleh beberapa perusahaan besar. Berdasarkan hasil penelitian dari Widjaja 
(2010) dalam Setyawan (2014) yang mengemukakan bahwa pangsa pasar industri ritel hanya dikuasai beberapa perusahaan. Pangsa pasar minimarket pada tahun 2010 dikuasai oleh dua perusahaan yaitu Alfamart dengan pangsa pasar sebesar 40,8\% dan Indomaret menguasai 43,2\% pangsa pasar. Perusahaan-perusahaan Hero, Carrefour, Superindo, Foodmart, Ramayana dan Yogya secara bersama-sama menguasai $76 \%$ pangsa pasar supermarket. Pangsa pasar Hypermarket 50\% dikuasai oleh Carrefour, sisanya menjadi milik Hypermart dengan $21 \%$ pangsa pasar dan Giant yang menguasai $18,5 \%$ pangsa pasar.

Penelitian lain yang dilakukan Kurniati dan Yanfitri (2010) menunjukkan bahwa dalam industri manufaktur yang berperan sebagai pemasok bagi industri ritel juga terjadi struktur pasar oligopoli karena fenomena perbedaaan kemampuan perusahaan bertahan dalam pasar kompetitif. Perusahaan yang keluar karena tidak mampu bersaing adalah perusahaan kecil dan para pemain baru juga perusahaan kecil yang tidak mampu bertahan lama. Perusahaan yang bertahan dari tahun 70-an sampai sekarang adalah perusahaan manufaktur besar karena kekuatan sumber daya mereka. Penelitian dari Setyawan (2014) menunjukkan adanya kesenjangan kekuasaan antara pemasok dan peritel dalam hubungan bisnis mereka. Nilai koefisien negatif dari pengaruh kesenjangan kekuasaan pada kinerja strategis dalam hubungan bisnis antara pemasok dan peritel dalam penelitian ini menunjukkan sebuah isu penting industri di Indonesia, yaitu ketidakadilan perdagangan. Konstruk kesenjangan kekuasaan yang berpengaruh negatif pada kinerja strategis perusahaan menunjukkan adanya eksploitasi kekuatan dan kontrol dari perusahaan besar pada UMKM di Indonesia. Perusahaan besar mempunyai kemampuan untuk melakukan kontrol terhadap UMKM untuk kepentingan bisnis mereka. Kontrol dilakukan dengan mengatur standar produk, pelayanan dan penentuan harga serta mekanisme pembayaran. Dalam kondisi tereksploitasi ini UMKM harus bertahan. Mereka tetap bertahan dalam hubungan bisnis yang eksploitatif ini dengan keuntungan kecil. Pilihan UMKM untuk tetap bertahan dalam hubungan pertukaran yang eksploitatif ini karena biaya untuk berganti mitra bisnis lebih mahal. Namun, beberapa UMKM peritel juga mempunyai posisi tawar yang lebih baik karena mereka dianggap mitra strategis oleh pemasok dari perusahaan besar. Peritel ini dianggap strategis karena lokasi bisnis mereka menguntungkan bagi pemasok perusahaan besar.

Hasil penelitian dari Martadisastra (2017) menunjukkan bahwa kinerja pemasok dalam rantai pasokan ritel moderen dipengaruhi cukup kuat oleh kondisi persaingan. Semakin ketat tingkat persaingan maka kinerja pemasok dalam rantai pasokan ritel moderen cenderung semakin erat dan berpotensi meningkatkan kinerja pemasok, namun pengaruh persaingan dalam implementasinya didominasi oleh ritel moderen yang secara ekspansif mengembangkan jaringan gerai dan cenderung memenuhi ekspektasi konsumen, sehingga terjadi peningkatan konsentrasi dan kekuatan posisi tawar dan kekuatan beli ritel moderen. Selain pihak pemasok hanya terfokus memperebutkan akses pasar, sehingga kekuatan posisi tawar pemasok sangat lemah. Kekuatan beli berpengaruh lemah terhadap kinerja pemasok dalam rantai pasokan ritel modern dipengaruhi lemah oleh kekuatan beli. Hasil penelitian menunjukkan bahwa tidak seluruh aspek kinerja pemasok dalam rantai pasokan dipengaruhi oleh kekuatan 
beli. Diindikasikan bahwa dalam implementasi kekuatan beli terjadinya berupa pembebanan biaya berlebihan terhadap pemasok.

\section{Relationship Marketing}

Relationship marketing adalah suatu proses untuk menciptakan, mempertahankan dan meningkatkan hubungan- hubungan yang kuat dengan para pelanggan dan stakeholder lainnya. Selain merancang strategi baru untuk menarik pelanggan baru dan menciptakan transaksi dengan mereka, perusahaan terus menerus sedang berjuang mati-matian untuk mempertahankan pelanggan yang ada dan membangun relasi jangka panjang yang mampu mendatangkan laba dengan mereka (Kotler \& Amstrong, 2010). Menurut Sivesan (2012) bahwa relationship marketing adalah konsep yang sangat penting untuk menarik dan mempertahankan pelanggan dalam sebuah organisasi. Dalam dunia bisnis modern, fokus pemasaran mencerminkan pergerakan perubahan dari pemasaran transaksional ke relationship marketing. Membangun, memelihara dan selalu meningkatkan hubungan pelanggan merupakan aspek penting dari bisnis. Konsep relationship marketing secara luas dipahami, baik itu secara akademis dan profesional dimana tujuannya adalah untuk meningkatkan hubungan yang kuat dan menjadikan pelanggan yang acuh tak acuh menjadi loyal.

Velnampy dan Sivesan (2012) juga mengatakan bahwa relationship marketing merupakan salah satu strategi pemasaran kontemporer untuk semua perusahaan demi memenuhi kebutuhan dan keinginan pelanggan. Dilihat dari sudut pandang pelanggan, faktor-faktor penting yang digunakan untuk memenuhi kebutuhan para pelanggan adalah adanya kepercayaan, komitmen, mutualitas, dan hubungan jangka panjang dengan pelanggan. Relationship marketing menurut Saputra dan Ariningsih (2014) merupakan sebuah konsep strategi pemasaran yang berupaya menjalin hubungan jangka panjang dengan para pelanggan, yaitu mempertahankan hubungan yang kokoh dan saling menguntungkan antara penyedia jasa dan pelanggan yang dapat membangun transaksi ulangan dan menciptakan loyalitas pelanggan. Satu hal yang sangat penting bagi perusahaan adalah membina hubungan yang baik dengan para pelanggan, pegawai, pemasok, distributor dan partner-partner distribusinya karena hubungan baik akan menentukan nilai masa depan perusahaan yang bersangkutan. Relationship marketing adalah proses berkelanjutan yang mensyaratkan suatu perusahaan agar menjalin komunikasi tetap dengan konsumen untuk memastikan tujuan tercapai dan memadukan proses relationship marketing kedalam rencana strategi sehingga memungkinkan perusahaan mengelola sumber daya dengan baik dan memenuhi kebutuhan konsumen di masa mendatang. Hubungan yang hangat bisa mencairkan kebekuan. Hubungan itu harus didasarkan oleh prinsip-prinsip ketulusan dan saling mendukung, bukan sekedar hubungan transaksional yang semu dan semata-mata karena perintah kerja atau hanya untuk mencarai keuntungan semata. Bila pemasar berdiri dipihak pelanggan dan memandang masalah yang dihadapi pelanggan juga sebagai masalahnya lalu berusaha memecahkan secara bersamasama, maka hubungan jangka panjang ini akan dirasakan oleh kedua belah pihak. 


\section{Tujuan Relationship Marketing}

Tujuan utama relationship marketing menurut Sivesan (2012) adalah untuk meningkatkan hubungan yang kuat antara pemasar dan palanggan dengan cara mengkonversi atau menjadikan pelanggan yang acuh tak acuh menjadi lebih loyal. Sisi lain dari tujuan utama relationship marketing sebenarnya adalah untuk menemukan lifetime value dari pelanggan. Setelah lifetime value didapat, tujuan selanjutnya adalah bagaimana agar lifetime value masing-masing kelompok pelanggan dapat terus diperbesar dari tahun ketahun. Setelah itu, tujuan ketiganya adalah bagaimana menggunakan profit yang didapat dari dua tujuan pertama untuk mendapatkan pelanggan baru dengan biaya yang relatif murah.

\section{Dimensi Relationship Marketing}

Kebanyakan penelitian mengenai Relationship Marketing selalu menekankan dimensi Trust dan Commitment, dan juga menyatakan Gratitude (rasa syukur) juga ikut mengambil peran dalam mempengaruhi Relationship Marketing (Palmetier, 2009). Dalam jurnal Velnampy dan Sivesan (2012) ada 4 kunci utama dalam relationship marketing, yaitu Trust, Equity, Empathy, Commitment. Adapun menurut Saputra dan Ariningsih (2014) dimensi relationship marketing meliputi kepercayaan, komitmen, kompetensi, komunikasi, dan kemampuan penanganan konflik. Menurut Chattananon dan Trimetsoontorn (2009), dimensi dari relationship marketing adalah Trust, Commitment, Co-operation, Communication, Shared Values, Conflict, Power, Non-opportunistic behavior, Interdependence. Dalam penelitiannya sendiri Chattananon menggunakan Bonding, Empathy, Reciprocity dan Trust sebagai dimensi dari relationship marketing. Sedangkan menurut Sivesan (2012) ada 4 faktor yang mempengaruhi relationship marketing, diantaranya Trust, Commitment, Communication dan conflict handling, yaitu :

1. Kepercayaan

Kepercayaan secara umum dipandang sebagai unsur mendasar bagi keberhasilan relationship marketing. Tanpa adanya kepercayaan suatu hubungan tidak akan bertahan dalam jangka panjang. Morgan dan Hunt (1994) menyatakan kepercayaan sebagai landasan strategi partnership, ketika terdapat pihak-pihak yang mempunyai keinginan untuk komit atau mengikat diri mereka pada suatu hubungan tertentu. Kepercayaan merupakan faktor terbentuknya komitmen karena komitmen mencakup faktor-factor kepercayaan dan pengorbanan. Komitmen tidak akan terbentuk tanpa adanya kepercayaan. Masih menurut Morgan dan Hunt (1994) bahwa kepercayaan secara signifikan mempengaruhi komitmen dalam suatu hubungan. Kepercayaan juga merupakan keyakinan yang dimiliki dalam hubungan dengan partner kerja terkait dengan sikap jujur dan saling membantu satu sama lain. Kepercayaan dapat tercipta ketika suatu pihak merasa nyaman melakukan pertukaran dengan pihak lain yang dengan penuh kejujuran dan dapat dipercaya. Untuk mendapatkan kepercayaan dari pelanggan maka perusahaan harus melakukan komunikasi secara efektif, mengadopsi norma-norma yang diyakini pelanggan dan menjauhi penilaian yang negatif. 
Kepercayaan adalah penting karena menyediakan dasar untuk kerjasama masa depan dan keyakinan salah satu pihak yang kebutuhannya akan digenapi di masa depan dengan tindakan yang dilakukan oleh pihak lain. Setelah kepercayaan didirikan, perusahaan belajar untuk mengkoordinasi dan berupaya bersama-sama tidak semata-mata untuk kepentingan sendiri. Kegagalan terbesar dalam hubungan antara konsumen dan pemasar adalah kurangnya kepercayaan. Berdasarkan kepercayaan pelanggan kemungkinan akan merekomendasikan perusahaan kepada pelanggan yang lain, kepercayaan didasarkan pada pengalaman masa lalu dan dijadikan perkiraan untuk perilaku dimasa yang akan datang, kepercayaan dan komitmen memiliki pengaruh dalam menciptakan sebuah nilai bagi pelanggan.

2. Komitmen

Komitmen merupakan suatu keyakinan antara pihak terkait yang menginginkan adanya hubungan yang terus menerus dan dinilai penting dalam rangka menjaga hubungan tersebut. Komitmen perusahaan merupakan inti dari relationship marketing. Komitmen perusahaan dapat diperoleh dengan cara perusahaan menjadikan pelanggan sebagai prioritas utama, berjangka panjang dan berdasarkan pada hubungan yang saling menguntungkan. Komitmen perusahaan juga dapat diartikan sebagai janji atau ikrar perusahaan untuk memelihara hubungan yang telah terjalin dengan baik, karena hubungan tersebut memiliki arti penting. Komitmen perusahaan dapat ditujukan dengan terus menerus melakukan pembelajaran untuk menyediakan kebutuhan pelanggan dan kualitas layanan akan meningkatkan kepuasan pelanggan, yang pada akhirnya akan membawa perusahaan pada terciptanya hubungan yang erat dengan pelanggannya.

3. Komunikasi

Ketika suatu konflik muncul di dalam suatu perusahaan, penyebabnya selalu diidentifikasikan sebagai hasil dari komunikasi yang kurang baik. Perusahaan harus mengelola komunikasi dengan baik karena komunikasi yang gagal kemungkinan dapat menyebabkan hal yang merugikan seperti kesalahpahaman atau kebingungan. Keefektifan komunikasi merupakan kemudahan mendapatkan informasi yang benar dan tepat sehingga pelanggan yang ingin melakukan transaksi dapat secara langsung mengambil keputusan untuk memilih sesuai dengan kebutuhannya, ketepatan informasi yang diperoleh secara tidak langsung dapat mempengaruhi loyalitas pelanggan. Komunikasi merupakan sarana yang sangat penting ketika ingin membangun hubungan dengan seseorang. Komunikasi merupakan alat perekat hubungan antara perusahaan dengan pelanggannya, sehingga komunikasi mempunyai peran vital dalam membina hubungan. Perusahaan yang orientasinya berusaha memenuhi keinginan dan kebutuhan pelanggan serta berusaha mendapatkan keuntungan yang berkelanjutan sangat membutuhkan peran komunikasi.

Keberhasilan sebuah komunikasi dapat dipengaruhi oleh beberapa hal, antara lain kejelasan ide yang ingin disampaikan, kesamaan persepsi antara pengirim dan penerima informasi, tidak adanya distorsi, dan saluran komunikasi yang tepat. Proses komunikasi juga mempengaruhi kesuksesan hubungan antara perusahaan dengan pelanggannya. Komunikasi dalam relationship marketing 
berhubungan dengan nilai yang diperoleh pelanggan, memberikan informasi yang tepat dan dapat dipercaya serta informasi mengenai adanya perubahan jasa yang ditawarkan, dan komunikasi yang proaktif ketika terjadi masalah antara perusahaan dan pelanggan. Pelanggan selalu menginginkan terciptanya komunikasi yang efektif dengan perusahaan, komunikasi yang baik tentunya dapat meningkatkan kepercayaan pelanggan terhadap perusahaan. Melalui komunikasi, pelanggan juga dapat mengemukakan ketidakpuasannya sehingga dapat dijadikan acuan bagi perusahaan untuk memperbaiki kinerjanya. Jika relationship marketing ingin berhasil maka harus menyertakan semua pesan yang ada dalam komunikasi pemasaran, hal ini diperlukan dalam menciptakan, memelihara dan memperluas hubungan dengan pelanggan.

\section{Konflik}

Dalam setiap hubungan social maupun ekonomi selalu terdapat rasa saling ketergantungan diantara semua pihak. Perusahaan dan pelanggan yang saling bergantung harus dapat menciptakan hubungan yang saling mendukung satu sama lain, namun pada kenyataannya hubungan yang saling bergantung tersebut dapat menciptakan konflik yang disebabkan oleh berbagai macam hal. Hal-hal yang berpotensi menimbulkan konflik tidak hanya hal-hal yang berkaitan dengan produk, namun juga berkaitan dengan pelayanan, keramahan (courtesy), sikap sopan santun, perhatian dan sikap kepedulian dari karyawan atau penyedia jasa tersebut. Kemampuan penanganan konflik mengacu pada kemampuan perusahaan untuk mencegah atau meminimalkan dampak dari hal-hal yang potensial dapat menimbulkan konflik dan kemampuan menyelesaikan konflik nyata yang sudah terjadi. Konflik dapat menjadi masalah yang serius di dalam perusahaan dan kemungkinan berpotensi menurunkan kinerja jika konflik tersebut dibiarkan berlarut-larut tanpa penyelesaian. Sivesan (2012) menyatakan bahwa jika suatu perusahaan dapat dipercaya, berkomitmen untuk layanan, dapat diandalkan, efisien dalam berkomunikasi dengan pelanggan dan mampu menangani konflik dengan baik, maka konsumen akan cenderung untuk setia terhadap produk. Sivesan juga menyarankan bahwa perusahaan harus menjaga hubungan baik dengan para pelanggannya untuk mendapatkan loyalitas.

Keempat dimensi relationship marketing tersebut merupakan satu kesatuan yang saling berkaitan, yang bertujuan untuk mewujudkan hubungan yang baik antara perusahaan dengan pelanggannya sehingga akan tercipta suatu hubungan yang saling menguntungkan dalam jangka panjang antara pelanggan dan perusahaan. Membangun kepercayaan, komitmen, kompetensi, komunikasi dan kemampuan penanganan konflik merupakan kunci pokok dalam penerapan relationship marketing.

\section{Loyalitas}

Kotler dan Keller (2012) menyatakan bahwa loyalitas pelanggan merupakan situasi yang pelanggan secara konsisten membelanjakan seluruh anggaran yang ada untuk membeli produk suatu layanan jasa dari penjual yang sama. Oliver (2010) menyatakan loyalitas adalah komitmen pelanggan bertahan secara mendalam untuk berlangganan kembali atau melakukan pembelian ulang produk/jasa terpilih secara konsisten pada masa yang akan datang, meskipun pengaruh situasi dan usaha-usaha 
pemasaran mempunyai potensi untuk menyebabkan perubahan perilaku. Banyak perusahaan menyadari bahwa kegiatan mempertahankan pelanggan lebih memberikan keuntungan dibandingkan jika perusahaan harus menarik pelanggan baru lagi Loyalitas merupakan respon perilaku, yang diekspresikan dalam jangka waktu yang panjang dan menghasilkan komitmen. Loyalitas dapat memberikan jaminan masa depan perusahaan yang lebih baik. Hubungan yang dekat dan berlangsung lama dengan para konsumen biasanya menunjukan adanya pengurangan biaya layanan, dikarenakan pengetahuan perusahaan mengenai kebutuhan-kebutuhan pelanggan semakin bertambah, sehingga perusahaan pada akhirnya mampu untuk menyediakan layanan yang lebih baik pada biaya yang lebih rendah. Pelanggan yang loyal merupakan aset terbesar bagi sebuah perusahaan. Hal ini karena pelanggan tersebut dapat berkomunikasi melalui kata dari mulut ke mulut yang menguntungkan tentang perusahaan atau produk yang digunakan sehingga dapat menarik pelanggan baru bagi perusahaan. Hal tersebut kemudian berdampak pada manfaat yang diperoleh dari penjualan, pendapatan dan laba perusahaan (Sivesan, 2012). Loyalitas dapat berwujud dalam hambatan untuk berpindah produk atau jasa, keinginan untuk merekomendasikan kepada orang lain, komentar yang baik dalam komunikasi word of mouth, kemauan mendorong orang lain untuk berbisnis dengan perusahaan yang bersangkutan dan kemauan membeli kembali. Loyalitas pelanggan tersebut disebabkan adanya hambatan perpindahan (switching barrier) yang besar. Disamping itu, loyalitas pelanggan juga dapat timbul karena pelanggan puas terhadap suatu barang atau jasa, sehingga ada kecenderungan untuk melanjutkan hubungan tersebut.

Dalam tulisan ini, loyalitas ditunjukan melalui hambatan untuk berpindah ke pesaing, keinginan untuk merekomendasikan kepada orang lain, komentar yang baik dan mendorong orang lain agar mau berbisnis atau kegiatan yang saling menguntungkan dengan pihak perusahaan. Loyalitas terjadi ketika seorang individu mempunyai ketertarikan dalam menjaga hubungan yang dekat, biasanya merupakan hasil dari serangkaian pengalaman positif di masa lalu. Salah satu faktor penting dalam membangun loyalitas adalah niat mendukung produk atau jasa dengan melakukan rekomendasi yang positif (positive word of mouth communication) berdasarkan pengalamannya. Jika pelanggan merasa puas dengan barang atau jasa yang diberikan maka pelanggan tersebut akan setia dan merekomendasikan produk tersebut kepada orang lain.

\section{Tahapan Perkembangan Loyalitas}

Oliver (2010) menyatakan bahwa loyalitas berkembang mengikuti empat tahapan, yaitu :

a. Tahap pertama yaitu loyalitas kognitif dimana pelanggan menggunakan informasi keunggulan suatu produk atau jasa atas produk atau jasa lainnya. Loyalitas kognitif didasarkan pada karakteristik fungsional, terutama biaya, manfaat dan kualitas.

b. Tahap kedua yaitu loyalitas afektif dimana sikap merupakan fungsi dari kognisi pada periode awal pembelian (masa sebelum konsumsi) dan merupakan fungsi dari sikap sebelumnya ditambah dengan kepuasan di periode berikutnya (masa setelah konsumsi). Munculnya loyalitas afektif didorong oleh faktor kepuasan yang 
menimbulkan kesukaan dan menjadi objek sebagai preferensi. Kepuasan pelanggan berkorelasi tinggi dengan niat pembelian ulang di waktu mendatang.

c. Tahap ketiga yaitu loyalitas konatif yang menunjukan suatu niat atau komitmen untuk melakukan sesuatu, pada masa sebelum konsumsi dan sikap pada masa mendatang setelah konsumsi. Merupakan suatu loyalitas yang mencakup komitmen mendalam untuk melakukan pembelian.

d. Tahap keempat yaitu loyalitas tindakan, aspek konatif berkembang menjadi perilaku dan tindakan. Merupakan kondisi yang mengarah pada kesiapan bertindak dan keinginan untuk mengatasi hambatan dalam melakukan tindakan tersebut. Pelanggan yang terintegrasi penuh pada tahap loyalitas tindakan dapat dihipotesiskan sebagai pelanggan yang rendah tingkat kerentanannya untuk berpindah ke produk lain.

Perkembangan konteks bisnis dalam era relationship marketing telah mengubah pendangan konvensional mengenai loyalitas pelanggan. Relationship marketing memaparkan bahwa loyalitas pelanggan harus dibangun dengan usaha keras dalam bentuk personalisasi dimana pelanggan menjadi inti dari aktivitas pemasaran. Griffin (2010) menyebutkan ada empat karakteristik pelanggan yang loyal, yaitu : a) melakukan pembelian secara teratur (makes regular repeat purchases), b) membeli di luar lini produk/jasa (purchases across product and services lines), c) merekomendasikan produk lain (refers other), dan d) menunjukkan kekebalan dari daya tarik produk sejenis dari pesaing (demonstrates an immunity to the full of the competition).

\section{Dimensi Loyalitas}

Menurut Mahmood et al (2012), terdapat dua dimensi pendekatan dalam mengukur loyalitas pelanggan yaitu : a) dimensi behavioural ; dimensi ini berkenaan dengan perilaku pelanggan terhadap pembelian berulang yang menunjukan preferensi terhadap merek atau jasa, b) dimensi attitudinal ; dimensi attitudinal berkenaan dengan maksud dari pelanggan untuk melakukan pembelian kembali dan merekomendasikan merek atau jasa kepada orang lain. Pelanggan yang memiliki maksud untuk membeli kembali dan merekomendasikan produk dan jasa kepada orang lain kemungkinan besar sebagai pelanggan yang loyal. Loyalitas pelanggan memang sangat diperlukan oleh perusahaan, namun yang terpenting adalah bagaimana usaha yang dilakukan oleh perusahaan dalam mewujudkan loyalitas pelanggan tersebut dengan sebaik-baiknya dan setinggi-tingginya, yaitu dengan cara melibatkan pelanggan di dalam proses bisnis perusahaan tersebut dan membina hubungan yang baik, karena jika perusahaan melibatkan pelanggan dalam proses bisnisnya, itu berarti mengajak pelanggan untuk menciptakan rasa memiliki terhadap perusahaan.

\section{METODE PENELITIAN}

Kajian ini dilakukan dengan metode deskriptif kualitatif, yaitu penelitian yang menggambarkan dan melukiskan keadaan obyek penelitian pada saat sekarang sebagaimana adanya berdasarkan fakta-fakta (Moleong, 2010). Metode penelitian kualitatif atau biasa disebut metode penelitian naturalistik adalah metode yang digunakan untuk meneliti pada objek yang alamiah, dimana peneliti adalah sebagai 
instrumen kunci Sugiyono (2010). Penelitian ini dilakukan pada bulan Juni hingga Desember 2017.

Teknik pengumpulan data dilakukan dengan metode wawancara, observasi, kajian dokumen hasil riset dan telaah teori-teori manajemen pemasaran. Subjek kajian ini atau sampel adalah pemasok (22 kelompok UMKM garam) dan 6 peritel dalam industri garam rakyat di Kabupaten Buleleng Provinsi Bali pada tahun 2017. Teknik analisis data dilakukan secara interaktif, mulai dari mengidentifikasi fakta, reduksi dan penyajian data, verifikasi dan menarik kesimpulan.

\section{HASIL PENELITIAN DAN PEMBAHASAN Hasil Penelitian}

Kelompok garam rakyat di Kabupaten Buleleng adalah kumpulan pelaku usaha produksi garam rakyat yang terorganisir yang dilakukan di lahan tambak, dengan cara perebusan (pelaku usaha produksi garam dengan cara perebusan) atau dengan cara mengolah air laut menjadi garam. Kabupaten Buleleng merupakan salah satu Kabupaten yang terletak dibagian utara Pulau Bali berbatasan dengan laut Jawa dan Bali, sehingga sebagian besar wilayah merupakan kawasan pesisir dengan panjang pantai $157,05 \mathrm{Km}$ dengan aneka ragam kekayaan laut (luas laut $319.680 \mathrm{ha}$ ) atau \pm $1.166,75 \mathrm{~km}^{2}$ untuk radius 4 mil, serta potensial untuk menghasilkan garam. Tepatnya di Kecamatan Gerokgak dan Tejakula merupakan daerah sentra produksi garam dan yang selama ini masih konsisten penduduknya melakukan usaha produksi garam. Berdasarkan data dari Dinas Perikanan dan Kelautan Kabupaten Buleleng tahun 2016 (www.bulelengkab.go.id), luas lahan tambak garam mencapai 1.088.871 M2 dengan produksi total 7.534.142 Kg dan potensi lahan produksi hampir 150 hektar. Produksi garam konsumsi dilakukan oleh 22 kelompok UMKM dengan jumlah anggota aktif 183 orang pada sentra produksi di Kecamatan Gerokgak dan Tejakula.

Kelompok UMKM garam konsumsi di Kabupaten Buleleng dalam memasarkan produksi garamnya melalui saluran pemasaran. Saluran pemasaran hasil produksi kelompok UMKM garam konsumsi di Kabupaten Buleleng dilakukan secara langsung ke konsumen akhir dan tidak langsung (seperti : melalui peritel). Hubungan bisnis ini terjadi dari tahun ke tahun antara pemasok yaitu dari kelompok UMKM yang memproduksi garam konsumsi dan peritel garam yaitu pedagang besar atau pengepul garam yang memasarkan garam lansung ke konsumen akhir baik untuk lokal, nasional dan ke luar negeri. Pemasaran garam di Kecamatan Gerokgak dan Tejakula hampir sebagian besar melalui peritel, yang kemudian dipasarkan ke seluruh Kabupaten/Kota di Bali.

Hasil produksi garam konsumsi dari pemasok/kelompok UMKM garam baik yang kualitas rendah sampai premium (garam pyramid), belum mampu menembus area pasar potensial secara langsung karena permintaan garam baik dari sisi kuantitas dan harga masih ditentukan oleh peritel. Relationship marketing selama ini terjadi antara pemasok/kelompok UMKM dan peritel garam karena adanya a) kepercayaan dan komitmen akan produksi garam dibeli oleh peritel, b) terdapat komunikasi dan penanganan konflik yang baik antara pemasok dan peritel, seperti : berkaitan dengan jumlah produksi dan harga garam. Kondisi ini dipengaruhi karena adanya faktor berupa kekuatan atau kekuasaan dari peritel dalam industri garam, sehingga pemasok menjadi 
loyal. Faktor tersebut seperti : 1) keterbatasan akses dan kuatnya jaringan peritel di Kabupaten Buleleng, Bali dan antar pulau, seperti : Surabaya dan Madura, 2) keterbatasan modal dan akses modal di lembaga keuangan, sehingga sebagian besar kelompok UMKM garam terjebak dalam sistem ijon dari peritel, 3) keterbatasan fasilitas produksi seperti : transportasi pengangkut produksi garam, status kepemilikan lahan dan gudang penampungan produksi garam, hal ini akan berimbas pada kerterikatan dan ketersediaan permintaan garam pada saat di luar masa produksi.

\section{Pembahasan}

Teori aliran pemikiran Industrial Marketing and Purchasing (IMP) berkaitan dengan analisis karakteristik hubungan bisnis antara pemasok dan peritel. Palmatier (2008) dalam Setyawan (2014) mengklasifikasikan aliran pemikiran dalam penelitian keterhubungan menjadi tiga yaitu aliran pemikiran Nordic, IMP dan Anglo Australian. Aliran pemikiran Nordic menitikberatkan pada diskusinya pada kualitas pelayanan untuk meningkatkan kualitas hubungan bisnis dan memperkuat loyalitas. Aliran IMP menekankan pembahasan pada karakteristik khusus dan faktor-faktor yang menyebabkan keberlanjutan dari hubungan bisnis antar organisasi. Aliran pemikiran ini didominasi oleh riset dengan latar business to business (B2B). Aliran pemikiran Anglo Australian menekankan diskusinya pada kualitas dan layanan konsumen. dalam Setyawan (2014) menyebutkan bahwa ada tiga dikotomi dalam ilmu pemasaran, yaitu pemasaran makro dan mikro, positif dan normatif dan organisasi profit dan non-profit. Pemasaran makro membahas tentang sistem pemasaran, dampak dari sistem pemasaran terhadap masyarakat dan dampak masyarakat terhadap sistem pemasaran. Pemasaran mikro berfokus pada aktivitas pemasaran pada level unit individual dan pemasaran internal dalam perusahaan. Pemasaran positif mencoba mendeskripsikan, menjelaskan, memprediksi dan memahami aktivitas pemasaran dan fenomena yang aktual yang ada. Pemasaran normatif mendeskripsikan apa yang harus dilakukan organisasi atau individu marketing serta apa jenis sistem pemasaran seperti apa yang harus dimiliki oleh masyarakat.

Hasil kajian hubungan bisnis (B2B) pemasok dan peritel garam dalam industri garam di Kabupaten Buleleng terhadap 22 kelompok UMKM garam dan 6 peritel garam menunjukkan kuatnya pengaruh kekuatan atau kekuasaan dari peritel dalam relationship marketing yang berdampak pada loyalitas pemasok.

\section{KESIMPULAN DAN SARAN Kesimpulan}

Perbedaan kekuasaan antar perusahaan yang menjalin hubungan bisnis adalah sesuatu yang tidak terhindarkan karena ada kalanya sebuah perusahaan harus menjalin hubungan bisnis dengan mitra bisnis perusahaan besar untuk meningkatkan kinerja ekonominya melalui peningkatan loyalitas yang berdampak secara jangka panjang.. Pemahaman, identifikasi dan kemampuan menggunakan strategi pengaruh akan memperkuat posisi tawar-menawar pelaku bisnis terhadap mitra bisnis mereka. Hal ini bisa menghindarkan dari resiko tereksploitasi oleh kekuasaan yang dominan.

Dalam relationship marketing pemasok dan peritel dalam industri garam di Kabupaten Buleleng, terdapat pengaruh kekuasaan atau kekuatan peritel yang membuat 
pemasok menjadi loyal.Faktor tersebut karena : 1) keterbatasan akses dan kuatnya jaringan peritel, 2) keterbatasan modal dan aksesnya sehingga terjebak dalam sistem ijon dari peritel, 3) keterbatasan fasilitas dan lahan produksi garam.

\section{Saran}

Pemasok yang jika dilihat dari skala perusahaan adalah sebagian besar merupakan perusahaan kecil atau kategori UMKM. Hal ini yang menjadi urgensi bagi pemangku kepentingan yaitu pemerintah yang mempunyai wewenang dalam menerbitkan kebijakan dalam mengatur hubungan bisnis pemasok (sebagian besar UMKM) dan peritel besar/modern. Posisi pemerintah (dalam hal ini adalah pemerintah Kabupaten Buleleng dan Kementrian Perikanan dan Kelautan) sebagai penyusun dan penegak regulasi bisnis bisa mengambil manfaat dari hasil-hasil kajian dan penelitian yang telah dilakukan dan bisa menjadi dasar bagi pemangku kebijakan untuk menyusun dan menegakkan sebuah kebijakan sebagai dasar bagi kemitraan bisnis antara perusahaan besar dan perusahaan kecil atau dalam kategori UMKM. Misalnya : ada tiga kemungkinan pola hubungan bisnis antar perusahaan dilihat dari ukuran perusahaan, yaitu hubungan bisnis antara perusahaan besar, antara perusahaan besar dan perusahaan kecil atau dalam kategori UMKM dan antara sesama perusahaan kecil atau dalam kategori UMKM. Perusahaan kecil atau dalam kategori UMKM sangat beresiko tereksploitasi oleh perusahaan besar karena disparitas kekuasaan antar dua perusahaan tersebut. Eksploitasi ekonomi dalam jangka panjang bisa mengganggu perkembangan bisnis. Dalam pola hubungan bisnis seperti ini, pemerintah bisa menyusun dan menegakkan regulasi yang bertujuan melindungi dari praktek perdagangan yang mengeksploitasi secara jangka panjang.

\section{DAFTAR PUSTAKA}

Akman, G \& Yorur, B. 2012. Effects of Business to Business Relations on Customer Satisfaction and Loyalty in the Context of a Developing Country. American Journal of Industrial and Business Management 2

Andersson, Pia \& Karlstrom, Klara. 2014. Factor influencing a Customer's Loyalty in B2B relationship : a Qualitative Study of Relationship Marketing. Thesis Halmstad University.

Baghdadi, Waheed I. 2013. The Role of Cross-cultural B2B Relationship Marketing : an investigation of Saudi Telecom Company (STC). Thesis Bedfordshire University

Chattananon, A. \& Trimetsoontorn, J. 2009. Relationship marketing : a Thai case. International Journal of Emerging Markets, 4(3)

Dinas Perikanan dan Kelautan Kabupaten Buleleng. 2016. (www.bulelengkab.go.id),

Ehmke C, Fulton J, Akridge J, Erickson K, Communications E, Linton S. 2009. Industry Analysis : The Five Forces. Indiana (US) : AICC, Purdue University.

Griffin, Jill. 2010. Customer Loyalty How To Earn it, How Keep It. Kentucky : McGraw Hill.

Jain, M., Khalil, S., Johnston, W.J. and Cheng, J.M.S. 2014. The performance implications of power-trust relationship: the moderating role of commitment in 
the supplier-retailer relationship. Industrial Marketing Management, Vol. 43 No. 2

Mahmood Kiyani, Talat., Raza, Mohammad Ullah Khan Niazi., Abbas, Riffatand khan., \& Imran. 2012. The Relationship Between Brand Trust, Customer Satisfaction And Customer Loyalty (Evidence From Automobile Sector of Pakistan). Interdisciplinary Journal Of Contemporary Research In, Institute of Interdisciplinary Business Research 490 Vol 4, No 1

Kurniati, Yati \& Yanfitri. 2010. Dinamika Industri Manufaktur dan Respon Terhadap Siklus Bisnis. https://www.researchgate.net/publication/312647125

Kotler, Philip \& Amstrong, Gary. 2010. Principles of Marketing. 13 Edition. New Jersey .Upper Saddle River : Pearson Prentice Hall

Kotler, Philip dan Kevin Lane Keller. 2012. Marketing Management. Essex : Pearson Education Inc.

Martadisastra, Dedie S. 2017. Kinerja Pemasok dalam Rantai Pasokan Makanan Kemasan : Suatu Kajian Kasus di Indonesia. Jurnal Bisnis dan Manajemen : Kompetensi, Vol. 12 No. 1 Januari 2017

Moleong, Lexy. 2010. Metodologi Penelitian Kualitatif. Bandung : PT. Remaja Rosdakarya.

Oliver, R. L. 2010. Satisfaction : A Behavioral Perpective on The Customer. New York: McGraw-Hill.

Palmatier, Robert W. 2008. Relationship Marketing. Cambridge, Marketing Science Institute.

Saputra dan Ariningsih. 2014. Masa Depan Penerapan Strategi Relationship. Marketing pada Industri Jasa Perbankan. Jurnal Manajemen dan Bisnis, Volume 10 No. 1.

Setyawan, A Agus. 2013. Pengaruh Power Asymmetry \& Relationship Marketing pada Kinerja Strategis Perusahaan dalam Hubungan Bisnis antara Pemasok \& Peritel. Electronic Theses \& Dissertations (ETD) Gadjah Mada University, http://etd.repository.ugm.ac.id.

Sergio, Paulo MM., Gustavo, Luiz GM., Alberto, JC. \& El Faro, Omar. 2014. Relationship Analysis of B2B channels : a Case Study on Channel Relationships in Brazilian Agribusiness Companies. African Journal of Business Management, Vo. $8(21)$

Sivesan. 2012. Impact of Relationship Marketing on Customer Loyalty on Banking Sectors. Journals of South Academic Research. Volume 2, Issue 3

Sugiyono. 2010. Metode Penelitian Kuantitatif Kualitatif dan R\&D. Penerbit CV Alfabeta, Bandung.

Suvanto, Hannele. 2012. Constructing A Typology Of Trust In Asymmetrical Food Business Relationships. British Food Journal, Vol. 114 No. 7

Velnampy, T \& Sivesan, S. 2012. Customer Relationship Marketing and Customer Satisfaction: A Study on Mobile Service Providing Companies in Sri Lanka. https://www.journalofbusiness.org/index.php/GJMBR/article/view/827 